\title{
Interaction of Hydrogen Sulfide and Estrogen on the Proliferation of Vascular Smooth Muscle Cells
}

\author{
Hongzhu $\mathrm{Li}^{1,2}$, Sarathi Mani ${ }^{1}$, Wei Cao ${ }^{3}$, Guangdong Yang ${ }^{4}$, Christopher Lai ${ }^{5}$, Lingyun $\mathrm{Wu}^{3}$, Rui Wang ${ }^{1,2 *}$ \\ 1 Department of Biology, Lakehead University, Thunder Bay, Canada, 2 Department of Pathophysiology, Harbin Medical University, Harbin, China, 3 Department of Health \\ Science, Lakehead University, Thunder Bay, Canada, 4 The School of Kinesiology, Lakehead University, Thunder Bay, Canada, $\mathbf{5}$ Northern Ontario School of Medicine, \\ Lakehead University, Thunder Bay, Canada
}

\begin{abstract}
Hydrogen sulfide $\left(\mathrm{H}_{2} \mathrm{~S}\right)$ can be endogenously generated from cystathionine gamma-lyase (CSE) in cardiovascular system, offering a cardiovascular protection. It is also known that the lower risk of cardiovascular diseases in female is partially attributed to the protective effect of estrogen. The current study explores the interaction of $\mathrm{H}_{2} \mathrm{~S}$ and estrogen on smooth muscle cell (SMC) growth. In the present study, we found that the proliferation of cultured vascular SMCs isolated from wildtype mice (WT-SMCs) was inhibited, but that from CSE gene knockout mice (CSE-KO-SMCs) increased, by estrogen treatments. The expression of estrogen receptor $\alpha(E R \alpha)$, but not ER $\beta$, was significantly decreased in CSE-KO-SMCs compared with that in WT-SMCs. Exogenously applied $\mathrm{H}_{2} \mathrm{~S}$ markedly increased ER $\alpha$ but not ER $\beta$ expression. In addition, the inhibition of ER activation and knockdown of ER $\alpha$ expression in WT-SMCs or the overexpression of ER $\alpha$ in CSE-KO-SMCs reversed the respective effects of estrogen on cell proliferation. The expression of cyclin D1 was reduced in WT-SMCs but increased in CSE-KO-SMCs after estrogen treatments, which was reversed by knockdown of ER $\alpha$ in WT-SMCs or overexpression of ER $\alpha$ in CSE-KO-SMCs, respectively. The overexpression of cyclin D1 in WT-SMCs or knockdown of cyclin D1 expression in CSE-KO-SMCs reversed the effects of estrogen on cell proliferation. These results suggest that $\mathrm{H}_{2} \mathrm{~S}$ mediates estrogen-inhibited proliferation of SMCs via selective activation of ER $\alpha /$ cyclin D1 pathways.
\end{abstract}

Citation: Li H, Mani S, Cao W, Yang G, Lai C, et al. (2012) Interaction of Hydrogen Sulfide and Estrogen on the Proliferation of Vascular Smooth Muscle Cells. PLoS ONE 7(8): e41614. doi:10.1371/journal.pone.0041614

Editor: Tianqing Peng, University of Western Ontario, Canada

Received April 21, 2012; Accepted June 22, 2012; Published August 3, 2012

Copyright: (c) $2012 \mathrm{Li}$ et al. This is an open-access article distributed under the terms of the Creative Commons Attribution License, which permits unrestricted use, distribution, and reproduction in any medium, provided the original author and source are credited.

Funding: This study was supported by a Discovery Grant from Natural Sciences and Engineering Research Council of Canada. SM was supported by a research fellowship award from Heart and Stroke Foundation of Canada (HSFC). GY was supported by a New Investigator Award from HSFC. The funders had no role in study design, data collection and analysis, decision to publish, or preparation of the manuscript.

Competing Interests: The authors have declared that no competing interests exist.

*E-mail: rwang@lakeheadu.ca

\section{Introduction}

Acquired proliferative phenotype of vascular smooth muscle cells (SMCs) is associated with development and progression of numerous vascular proliferative conditions, such as primary atherosclerosis and post-angioplasty restenosis [1]. Women generally experience initial manifestations of coronary artery disease 10 years later than men, suggesting that estrogen may offer a cardiovascular protection [2]. It is well known that estrogen inhibits the proliferation of SMCs [3]. Estrogen can bind to estrogen receptors (ERs), including $\mathrm{ER} \alpha$ and $\mathrm{ER} \beta$, which are expressed in all vascular cell types and appear to mediate the inhibitive effects of estrogen on SMC proliferation [3,4].

Estrogen activates many intracellular signaling responses [5]. Estrogen-stimulated mitogen-activated protein kinase (MAPK) cascade plays a key role in the cellular signal transduction pathway in response to vascular stimuli [6]. MAPK family in mammalian cells consists of three major members including ERK (an extracelluar signal-regulated kinase), JNK (c-Jun Nterminal kinase) and p38 MAPK [7]. Each of these MAPK plays a unique role in the regulation of gene expression and intracellular metabolism related to growth and development, apoptosis, and cellular responses to external stresses [7]. Cyclin D1 and its associated cyclin-dependent kinases (CDK4 and 6) are key regulatory proteins in controlling the reentry of quiescent cells from G0 into G1 [8]. Cyclin D1 was also reported to mediate the inhibitory effect of estrogen on cell proliferation [9].

Hydrogen sulfide $\left(\mathrm{H}_{2} \mathrm{~S}\right)$ was traditionally viewed as a toxic gas detected in the contaminated environmental atmosphere [10]. Over the last decade, physiological importance of endogenously produced $\mathrm{H}_{2} \mathrm{~S}$ has been realized [11]. Two key enzymes in the transsulfuration pathway, cystathionine beta-synthase (CBS) and cystathioine gamma-lyase (CSE), produce $\mathrm{H}_{2} \mathrm{~S}$, pyruvate and ammonium using homocysteine and/or L-cysteine as substrates $[12,13]$. In some tissues, both CBS and CSE function to catalyze $\mathrm{H}_{2} \mathrm{~S}$ production. CSE is the major $\mathrm{H}_{2} \mathrm{~S}$-producing enzyme in vascular tissues [14]. As an important gasotransmitter in the cardiovascular system, $\mathrm{H}_{2} \mathrm{~S}$ has important physiological functions, such as anti-atherosclerosis, anti-inflammatory, vasodilatation, protection of ischemia injury, and antioxidant effects [12,14-16].

Although both estrogen and $\mathrm{H}_{2} \mathrm{~S}$ can inhibit $\mathrm{SMC}$ proliferation $[3,4,7,8,13]$, the interaction of $\mathrm{H}_{2} \mathrm{~S}$ and estrogen on SMC growth has been unknown. In the present study, we compared the effects of estrogen on the proliferation of SMCs from CSE knockout mice (CSE-KO-SMCs) and those from wild-type mice (WT-SMCs). The underlying cellular signaling mechanisms, including the activation of $\mathrm{ER} \alpha$, cyclin D1 and MAPK pathways, were further explored. 


\section{Materials and Methods}

\section{Materials}

Estrogen (17 $\beta$-estradiol) was from Sigma (St. Louis, MO). The anti-CSE antibody was purchased from Novus Biologicals (Littleton, CO). The anti-MAPK antibodies and different MAPK inhibitors were obtained from New England Biolabs (Camarillo, CA). Anti-cyclin D1 antibody was from Lab Vision Corporation (Fremont, CA). Anti-ER $\alpha, \mathrm{ER} \beta$ antibodies and siRNA for ER $\alpha$ as well as control siRNA were obtained from Santa Cruz Biotechnology (Santa Cruz, CA). Cyclin D1 siRNA and control siRNA were purchased from Ambion (Austin, TX). The plasmids pCMV-Cyclin Dl and pEGFP-C1-ER $\alpha$ were from Addgene (Cambridge, MA). Horseradish peroxidase-conjugated goat antirabbit IgG antibody and goat anti-mouse IgG antibody were from Sigma. All other chemicals were from Sigma or New England Biolabs.

\section{Isolation and Culture of SMCs}

Twelve-week-old male CSE-KO offspring and age matched male WT littermates on C57BL/6J $\times 129 \mathrm{SvEv}$ background were used to isolate primary SMCs from mesenteric arteries [17]. All animals were maintained on standard rodent chow and had free access to food and water. All animal experiments were conducted in compliance with the Guide for the Care and Use of Laboratory Animals published by the US National Institutes of Health (NIH Publication No. 85-23, revised 1996) and approved by the Animal Care Committees of Lakehead University, Canada. In brief, 12week male WT and CSE-KO mice were generally anaesthetized by intraperitoneal injection with a mixture of $10 \mathrm{mg} / \mathrm{kg}$ xylazine (Bimeda-MTC Animal Health, CA) and $100 \mathrm{mg} / \mathrm{kg}$ ketamine hydrochloride (BIONICHE Animal Health, CA). When mice have lost muscle tone and blink reflexes, pupils become fixed and respiration is regular, the operation was carried out. Mice were killed by decapitation. Small mesenteric arteries below the second branch of the main mesenteric artery were dissected out and kept
A
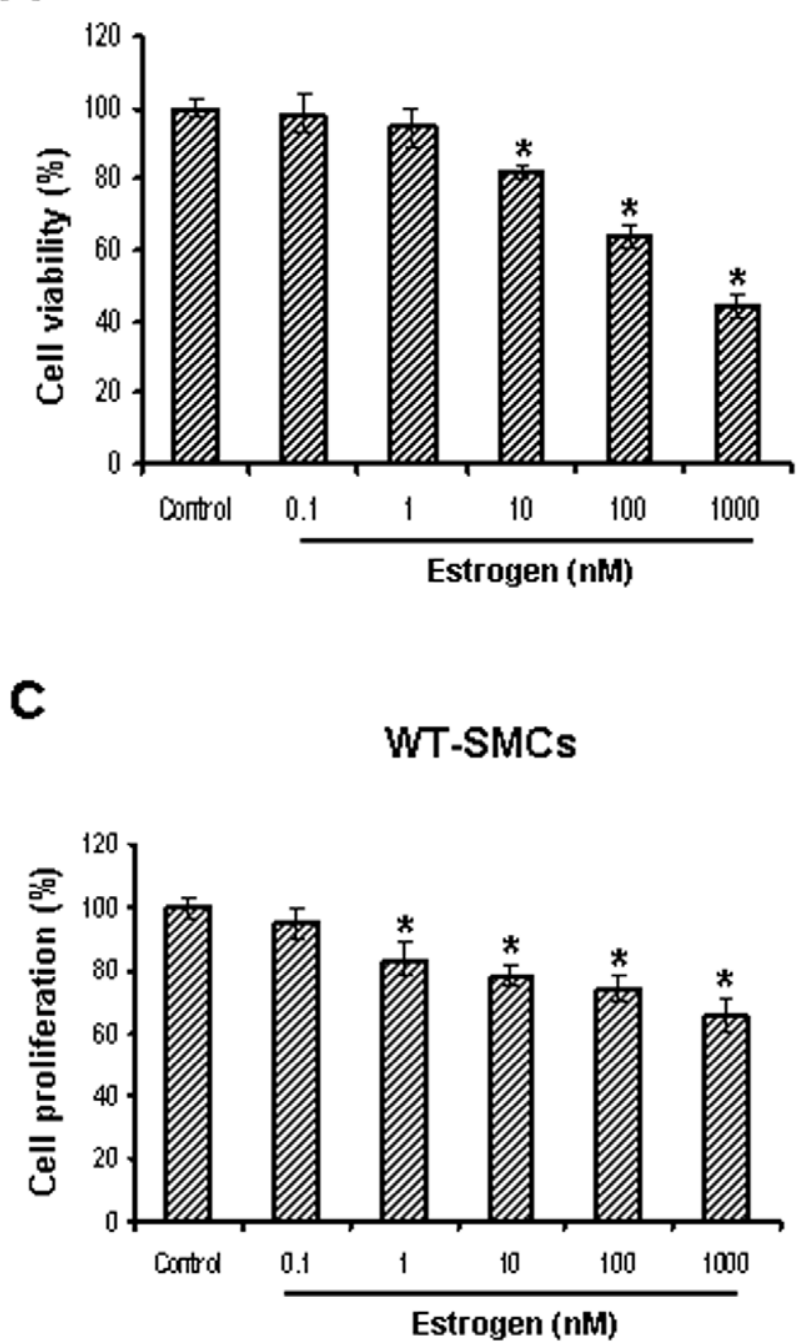

B
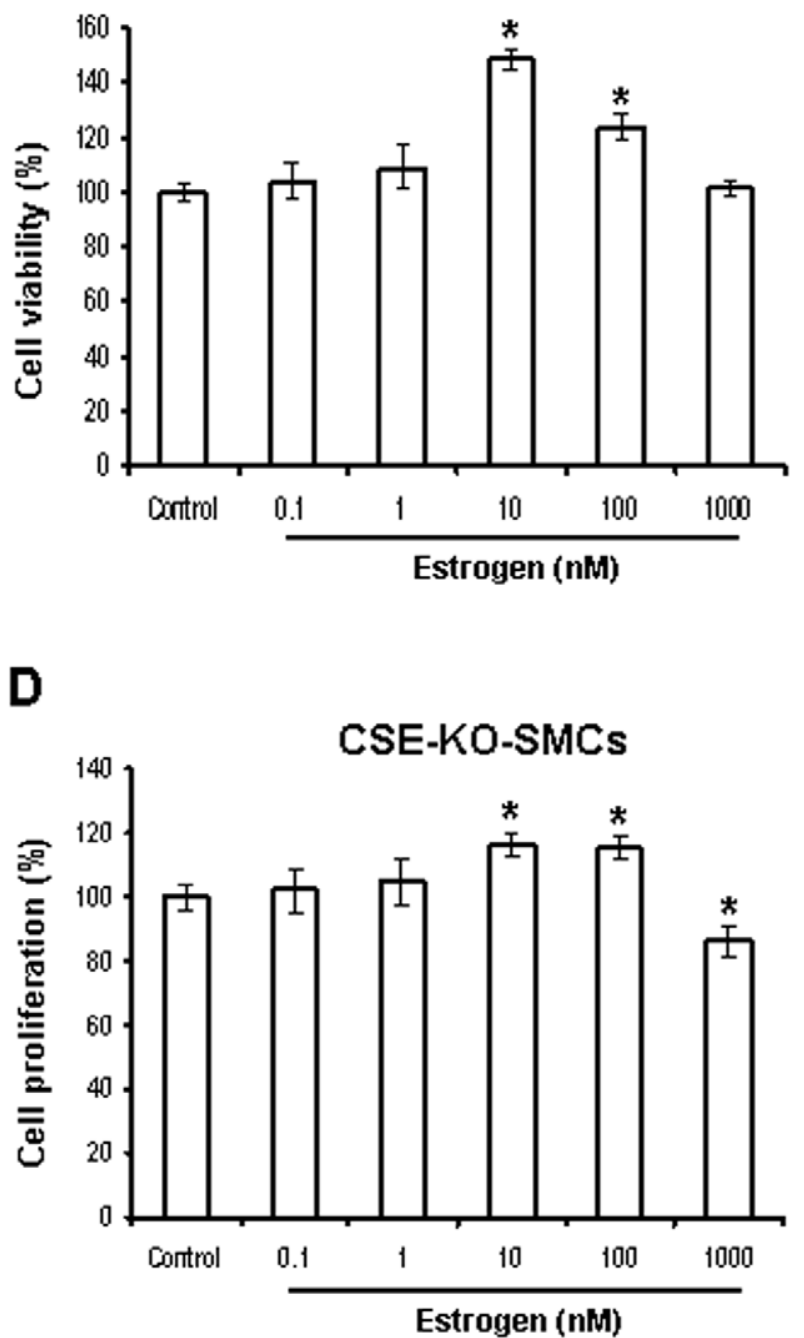

Figure 1. Inhibition of WT-SMC growth but promotion of CSE-KO-SMC growth by estrogen. WT-SMCS and CSE-KO-SMCS were treated with estrogen at the indicated concentrations for $72 \mathrm{~h}$, and then cell viability and cell proliferation were measured. Cell viability of WT-SMCs $(\boldsymbol{A})$ and CSE-KO-SMCs $(B)$ were measured by MTT assay and cell proliferation of WT-SMCs $(\boldsymbol{C})$ and CSE-KO-SMCs $(D)$ were analyzed by BrdU incorporation assay. The control cells without estrogen treatment were considered as $100 \%$ viable. Data were from five independent experiments. ${ }^{*} p<0.05$ vs. control group.

doi:10.1371/journal.pone.0041614.g001 
in ice-cold physiological salt solution (PSS) containing (in $\mathrm{mM}$ ) $\mathrm{NaCl}$ 137, KGl 5.6, $\mathrm{NaH}_{2} \mathrm{PO}_{4}$ 0.4, $\mathrm{Na}_{2} \mathrm{HPO}_{4}$ 0.4, $\mathrm{NaHCO}_{3} 4.2$, $\mathrm{MgCl}_{2} 1, \mathrm{CaCl}_{2} 2.6$, Hepes 10 , and glucose 5 with $\mathrm{pH}$ adjusted to 7.4 with $\mathrm{NaOH}$. The small arteries were cut into $5 \mathrm{~mm}$-long pieces, and incubated at $37^{\circ} \mathrm{C}$ in low-Ca ${ }^{2+}$ PSS $(0.1 \mathrm{mM} \mathrm{CaCl} 2)$ containing $1 \mathrm{mg} / \mathrm{ml}$ albumin, $0.5 \mathrm{mg} / \mathrm{ml}$ papain, and $1 \mathrm{mg} / \mathrm{ml}$ dithioerythritol for $30 \mathrm{~min}$, and for another $20 \mathrm{~min}$ in the $\mathrm{Ca}^{2+}$ free PSS containing $1 \mathrm{mg} / \mathrm{ml}$ albumin, $0.8 \mathrm{mg} / \mathrm{ml}$ collagenase, and $0.8 \mathrm{mg} / \mathrm{ml}$ hyaluronidase. Single cells were released by gentle trituration through a Pasteur pipette, stored in the nominally $\mathrm{Ca}^{2+}$-free PSS at $4^{\circ} \mathrm{C}$, and used the same day. These primary SMCs were grown in phenol red-free Dulbecco's modified Eagle's medium (DMEM) supplemented with 10\% fetal bovine serum (FBS), $100 \mathrm{U} / \mathrm{ml}$ penicillin, and $100 \mathrm{mg} / \mathrm{ml}$ streptomycin. The experiments were performed when the cells reached $70-80 \%$ confluence between passages 6 and 10. In all studies, cells were first incubated in the serum-free medium for $24 \mathrm{~h}$ and then $1 \%$ serum added together with different treatments, the media were changed every 2 days.

\section{Cell Viability Assay}

Cell viability was determined by the 3-(4,5-dimethylthiazol-2yl)-2,5-diphenyltetrazolium bromide (MTT) assay as described previously [18]. In brief, equal numbers of cells were seeded into each well of 96 -well plates for $24 \mathrm{~h}$. After different treatments, MTT (final concentration, $5 \mathrm{mg} / \mathrm{ml}$ ) was added to each well, and then the cells were incubated for $4 \mathrm{~h}$ at $37^{\circ} \mathrm{C}$. The cell culture medium was removed, and dimethyl sulfoxide ( $200 \mu \mathrm{l} /$ well $)$ was added. The absorbance of formazan products at $570 \mathrm{~nm}$ was measured in a FLUOstar OPTIMA microplate spectrophotometer (BMG LABTEch, Offenburg, Germany). The cells incubated with control medium were considered $100 \%$ viable.

\section{Cell Proliferation Assay}

Cell proliferation was assessed by bromodeoxyuridine (BrdU) incorporation as described previously [8]. SMCs were plated at equal numbers of cells $\left(2.0 \times 10^{3}\right.$ per well $)$ in a 96 -well plate for $24 \mathrm{~h}$ in the presence of $10 \% \mathrm{FBS}$. BrdU label was added into the culture media for another $24 \mathrm{~h}$. Incorporated BrdU was detected following the procedures provided by the manufacturer (Calbiochem, Gibbstown, NJ, USA). For the experiments with estrogen treatments the cells were first seeded in a 96-well plate for $24 \mathrm{~h}$ in media containing $10 \% \mathrm{FBS}$, and then changed to a serum-free medium for another $24 \mathrm{~h}$. Afterwards, 1\% FBS was added back together with estrogen $(0.1-1000 \mathrm{nM})$ for $48 \mathrm{~h}$ following BrdU label for additional $24 \mathrm{~h}$.

\section{Measurement of $\mathrm{H}_{2} \mathrm{~S}$ Production}

$\mathrm{H}_{2} \mathrm{~S}$ production rate was measured as described previously [19]. In brief, after different treatments, the cells were collected and homogenized in $50 \mathrm{mM}$ ice-cold potassium phosphate buffer (pH 6.8). The flasks containing the reaction mixture $(100 \mathrm{mM}$ potassium phosphate buffer, $10 \mathrm{mM}$ l-cysteine, $2 \mathrm{mM}$ pyridoxal 5phosphate, and $10 \%$ cell homogenates) and center wells containing $0.5 \mathrm{ml} 1 \%$ zinc acetate and a piece of filter paper $(2 \times 2.5 \mathrm{~cm})$ were flushed with $\mathrm{N}_{2}$ gas and incubated at $37^{\circ} \mathrm{C}$ for $90 \mathrm{~min}$. The reaction was stopped by adding $0.5 \mathrm{ml}$ of $50 \%$ trichloroacetic acid, and the flasks were incubated at $37^{\circ} \mathrm{C}$ for another $60 \mathrm{~min}$. The contents of the center wells were transferred to test tubes, each containing $3.5 \mathrm{ml}$ of water. Then $0.5 \mathrm{ml}$ of $20 \mathrm{mM} \mathrm{N}, \mathrm{N}-$ dimethyl-p-phenylenediamine sulfate in $7.2 \mathrm{M} \mathrm{HCl}$ and $0.5 \mathrm{ml}$ $30 \mathrm{mM} \mathrm{FeCl}_{3}$ in $1.2 \mathrm{M} \mathrm{HCl}$ was added. The absorbance of the resulting solution at $670 \mathrm{~nm}$ was measured 20 min later with a FLUOstar OPTIMA microplate spectrophotometer.

\section{Short Interfering RNA (siRNA) and Plasmid Transfection}

Transfection of SMCs by siRNA or plasmids (pCMV-Cyclin D1 and pEGFP-C1-ER $\alpha$ as well as corresponding control plasmid) was achieved by using the Lipofectamine ${ }^{\mathrm{TM}} 2000$ transfection agent from Invitrogen (Burlington, ON). In brief, SMCs were seeded at equal number of cells $\left(2.0 \times 10^{5}\right.$ per plate $)$ in $60 \mathrm{~mm}^{2}$ plates with the medium containing $10 \%$ FBS. The cells were plated to form $60-70 \%$ confluent monolayers for siRNA transfection, and $80-90 \%$ confluence for plasmid transfection. siRNA or plasmid and the transfection reagent complex were added to the serum-free medium for $4 \mathrm{~h}$, and the transfection continued for another $48 \mathrm{~h}$ (for siRNA transfection) or $24 \mathrm{~h}$ (for plasmid transfection) in serum-containing regular medium. After that, the cells were collected for detection of protein expressions with western blotting analysis.

\section{Western Blotting Analysis}

Cells were harvested and lysed. Equal amounts of proteins were boiled and separated with SDS-PAGE and electrophoretically transferred to a nitrocellulose membrane, as described previously [20]. In each lane of a 10\% sodium dodecyl sulfate-polyacrylamide gel electrophoresis, equal amounts of proteins were applied, electrophoresed and transferred to a polyvinylidene fluoride membrane. Membranes were blocked with Tris-buffered saline containing $5 \%$ non-fat milk at room temperature for $1 \mathrm{~h}$, then incubated overnight at $4{ }^{\circ} \mathrm{C}$ with primary antibody. The primary antibody dilutions were 1:1,000 for CSE, $\mathrm{ER} \alpha, \mathrm{ER} \beta$ and Cyclin D1, phosphorylated or total ERK, p38 MAPK, or JNK, and 1:10,000 for $\beta$-actin. The membrane was then washed three times with $1 \times$ Tris-buffer saline-Tween 20 (TBST) buffer and incubated in TBST solution with horseradish peroxidase-conjugated secondary antibody (diluted 1:5,000) for $1 \mathrm{~h}$ at room temperature on a shaker. Finally, the membrane was washed with TBST solution for 3 times. The immunoreactions were visualized with ECL and exposed to x-ray film (Kodak Scientific Imaging film, Kodak, Rochester, NY).

\section{Real-time PCR Analysis}

Total RNA was isolated using an RNeasy Mini Kit (Qiagen, Germantown, MD) and converted to cDNA with an iScriptTM cDNA Synthesis Kit (Bio-Rad, Hercules, CA). Real-time PCR was performed in an iCycler iQ5 apparatus (Bio-Rad) associated with the iCycler optical system software (version 3.1) using SYBR Green PCR Master Mix, as described previously [8]. The primers of $\mathrm{ER} \alpha$ were $5^{\prime}$-ATTCTGACAATCGACGCCAG-3' (forward) and $5^{\prime}$-GTGGATTGGTTTGTAGGTGG-3' (reverse). The primers for $\beta$-actin were $5^{\prime}$-ATGGTGGGAATGGGTCAGAA-3' (forward) and 5'-CTTTTCAGGGTTGGGCTTAG-3' (reverse). The PCR conditions were as follows: denaturation at $95^{\circ} \mathrm{C}$ for $60 \mathrm{~s}$, followed by 40 cycles of denaturation at $95^{\circ} \mathrm{C}$ for $15 \mathrm{~s}$, annealing at $55^{\circ} \mathrm{C}$ for $15 \mathrm{~s}$, and extension at $72^{\circ} \mathrm{C}$ for $45 \mathrm{~s}$. Relative mRNA quantification was calculated by using the arithmetic formula "2- $\Delta \Delta \mathrm{CT}$ ", where $\Delta \mathrm{CT}$ is the difference between the threshold cycle of a given target cDNA and an endogenous reference $\beta$-actin cDNA.

\section{Statistical Analysis}

All data were expressed as the mean $\pm \mathrm{SE}$ and represented at least three independent experiments. Statistical comparisons were made using student's $t$-test or one-way ANOVA followed by a post hoc analysis (Tukey test) where applicable. Significance level was set at $\mathrm{p}<0.05$. 
A

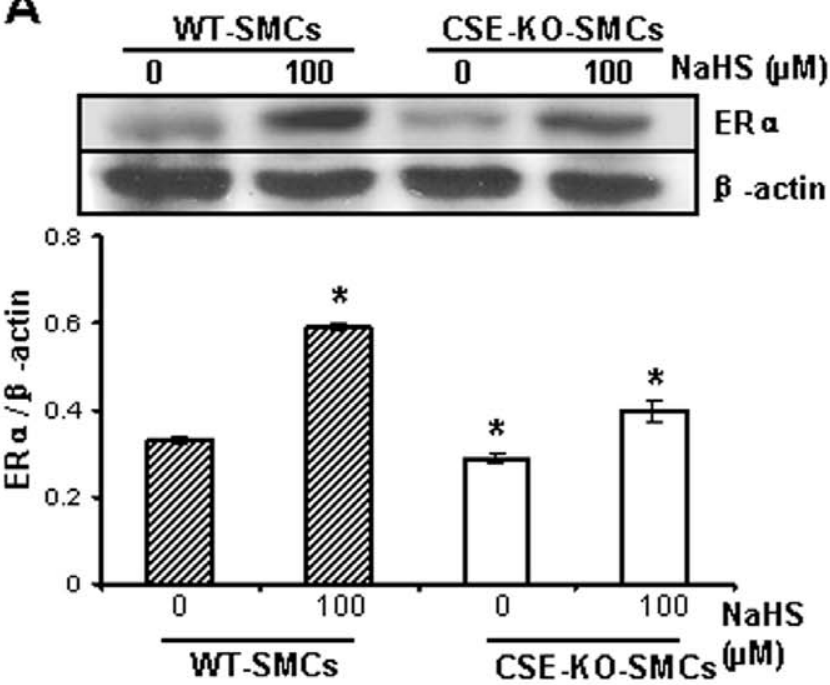

C
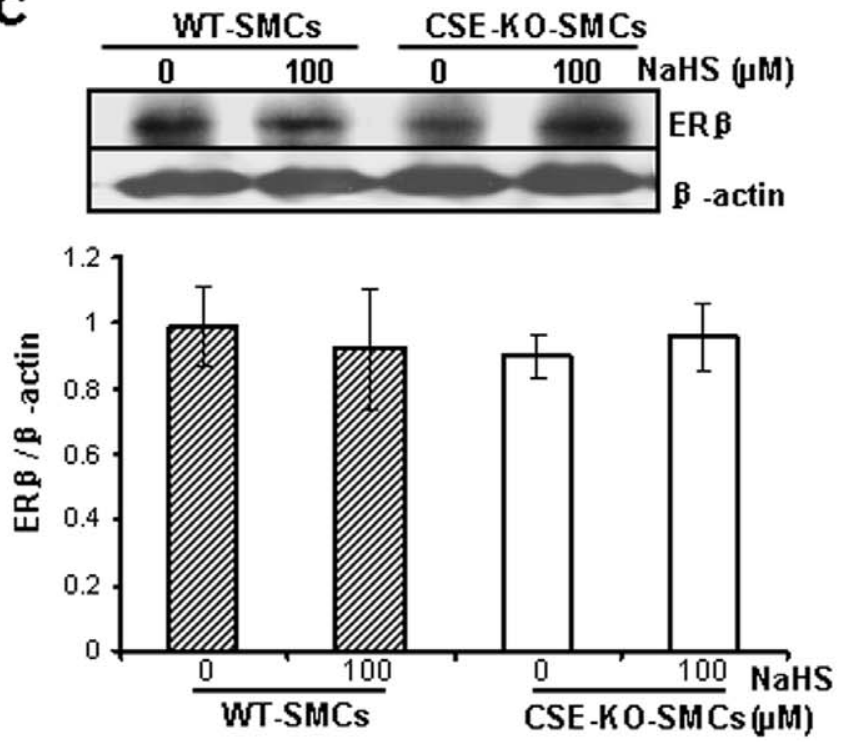

B

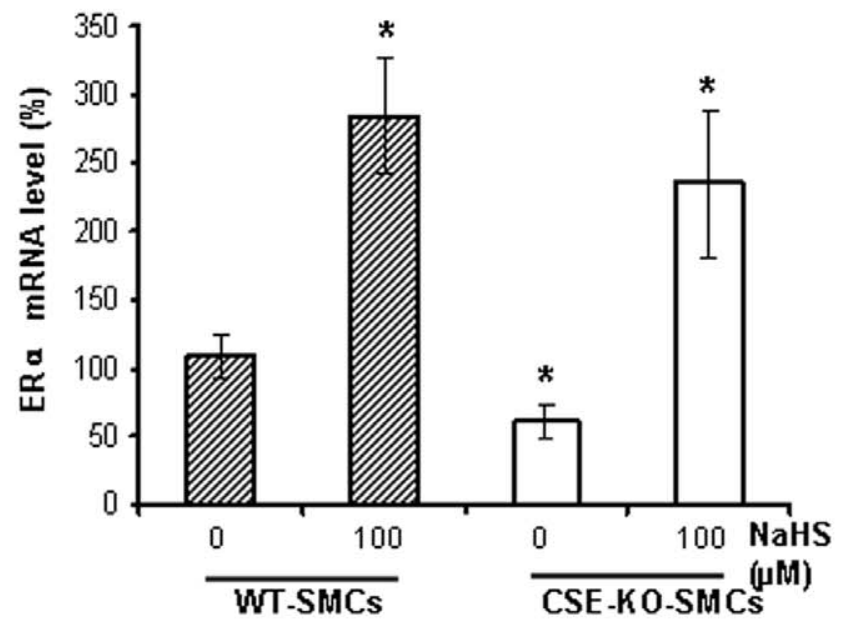

D

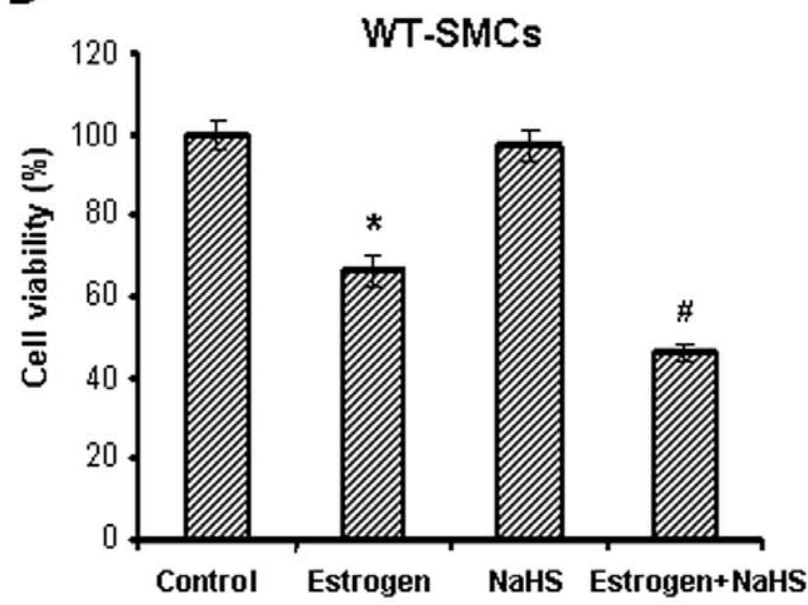

Figure 2. The effect of $\mathbf{H}_{2}$ S on ER $\alpha$ and ER $\beta$ expression. $\boldsymbol{A}, \mathrm{NaHS}$ up-regulated the protein expressions of ER $\alpha$ in both WT-SMCS and CSE-KOSMCs. The cells were treated with NaHS at $100 \mu \mathrm{M}$ for $24 \mathrm{~h} .{ }^{*} \mathrm{p}<0.05$ vs. WT-SMCs. $B$, NaHS up-regulated the expression of ER $\alpha$ mRNA in both WTSMCs and CSE-KO-SMCs. The cells were treated with NaHS at $100 \mu \mathrm{M}$ for $24 \mathrm{~h} .{ }^{*} \mathrm{p}<0.05 \mathrm{vs}$. WT-SMCs. $C$, NaHS had no effect on the protein expressions of ER $\beta$ in both WT-SMCs and CSE-KO-SMCs. D, NaHS potentiated the inhibitory effect of estrogen on the growth of WT-SMCs. After WTSMCs were treated with $100 \mathrm{nM}$ estrogen for $72 \mathrm{~h}$ in the presence or absence of $100 \mu \mathrm{M}$ NaHS, cell viability was measured. ${ }^{*} \mathrm{p}<0.05 \mathrm{vs}$. control group; ${ }^{\#} p<0.05$ vs. estrogen group. All data were from three independent experiments.

doi:10.1371/journal.pone.0041614.g002

\section{Results}

The Opposite Effects of Estrogen on the Growth of WTSMCS and CSE-KO-SMCS

Estrogen at 10 to $1000 \mathrm{nM}$ significantly decreased cell viability of WT-SMCs in a dose-dependent manner. However, at 10 to $100 \mathrm{nM}$ estrogen significantly increased cell viability of CSE-KO-SMCs (Figure 1A and 1B). Cell viability data was further confirmed by cell proliferation analysis (Figure 1C and 1D). At the concentrations higher than $100 \mathrm{nM}$, the stimulatory effect of estrogen on proliferation of CSE-KO-SMCs could not be detected (Figure 1D).
Effect of $\mathrm{H}_{2} \mathrm{~S}$ on ER $\alpha$ Activation

The physiological functions of estrogen are mostly mediated by estrogen receptors $[3,4]$. Our results showed that both mRNA and protein expressions of $\mathrm{ER} \alpha$ were significant higher in WT-SMCs than that in CSE-KO-SMCs, and treatment with $100 \mu \mathrm{M}$ NaHS (a $\mathrm{H}_{2} \mathrm{~S}$ donor) for $24 \mathrm{~h}$ up-regulated $\mathrm{ER} \alpha \mathrm{mRNA}$ and protein expressions in both WT-SMCs and CSE-KO-SMCs $(\mathrm{p}<0.05)$ (Figure 2A and 2B). We further found that $\mathrm{ER} \beta$ protein expression was not changed between WT-SMCs and CSE-KO-SMCs, and NaHS treatment had no effect on the expression of ER $\beta$ in both cells $(\mathrm{p}>0.05)$ (Figure 2C). In addition, NaHS at $100 \mu \mathrm{M}$ 
A

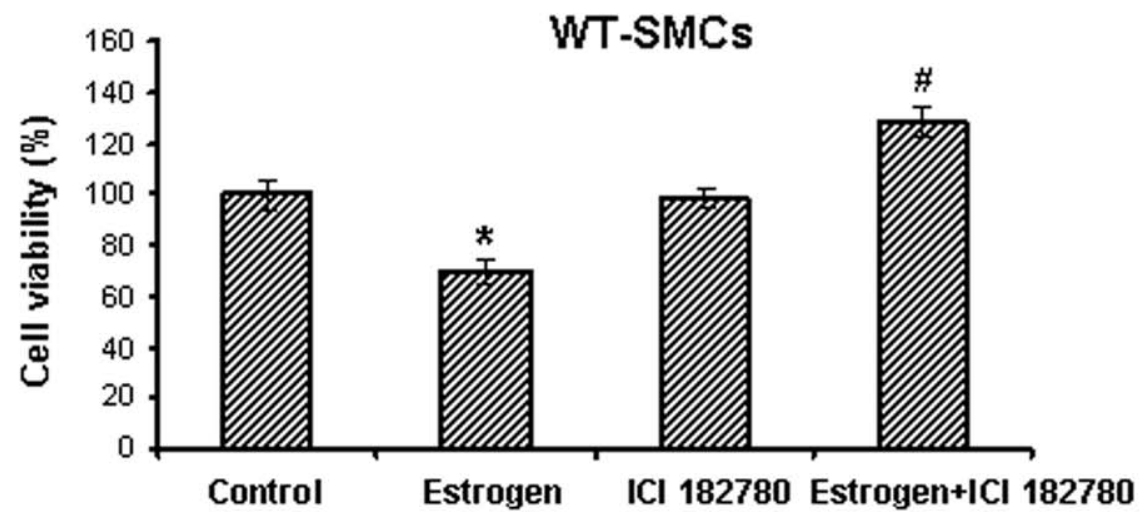

B
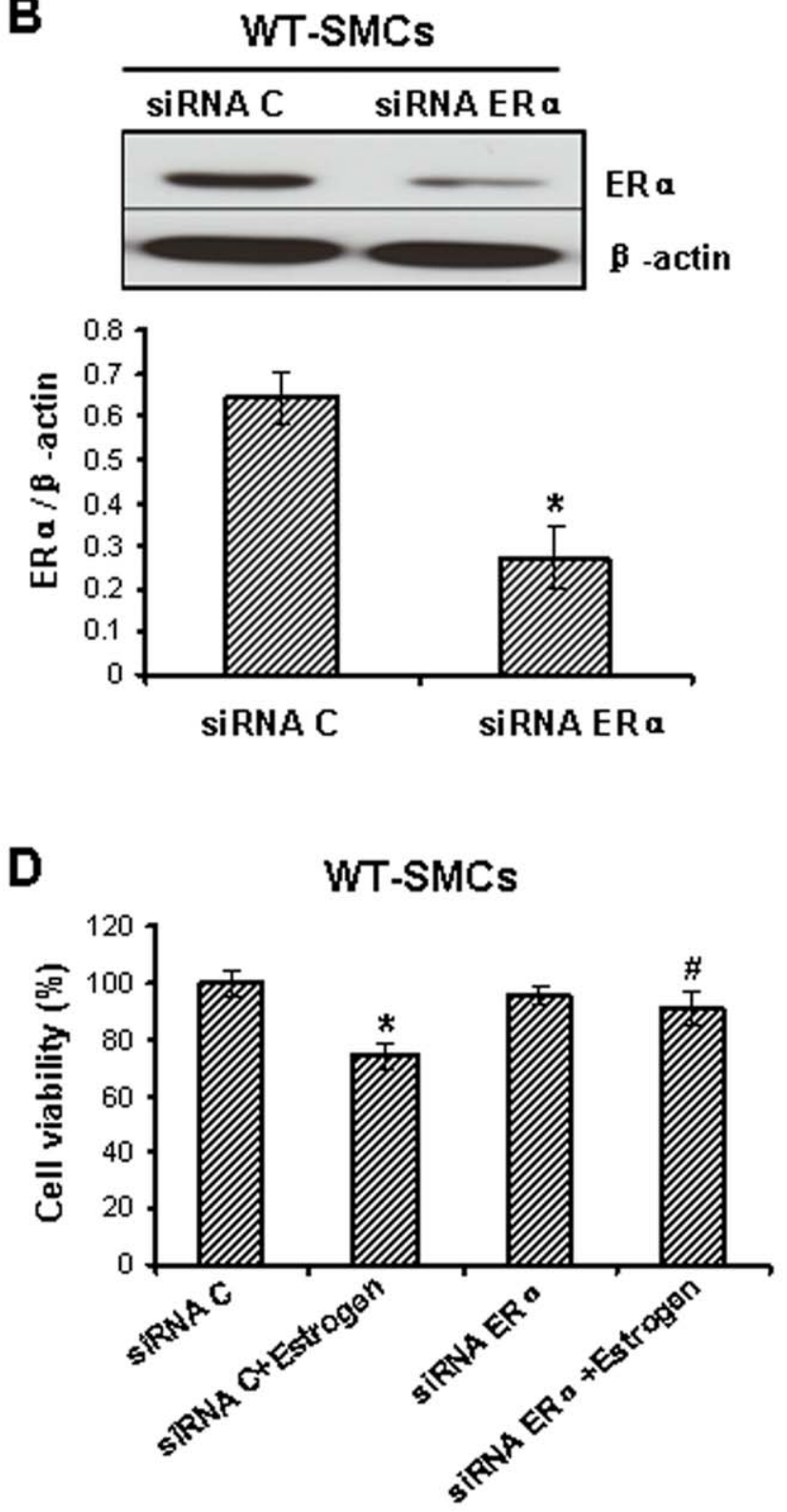

C

CSE-KO-SMCs
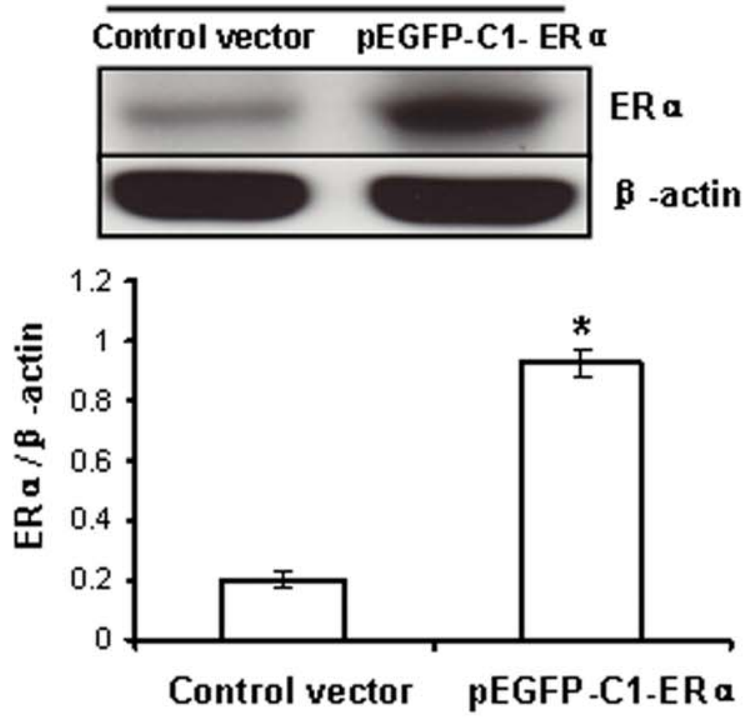

E

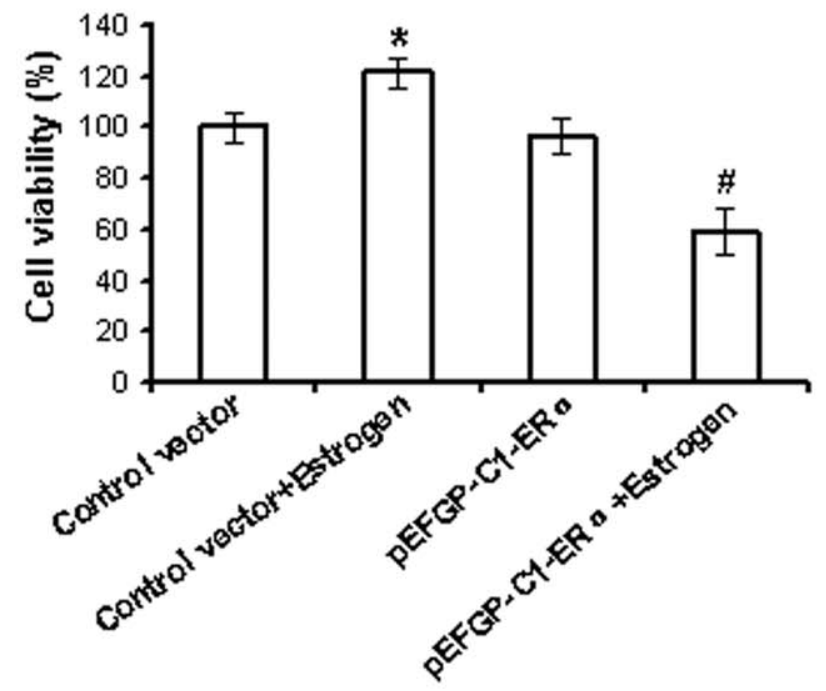


Figure 3. The role of ERa in the actions of estrogen on the growth of WT-SMCs and CSE-KO-SMCs. $A$, Blockage of ERs activity reversed estrogen-inhibited cell viability in WT-SMCs. The cells were treated with $10 \mu \mathrm{M} I C I 182780$ for $30 \mathrm{~min}$ following another $72 \mathrm{~h}$ treatment with $100 \mathrm{nM}$ estrogen. ${ }^{*} p<0.05$ vs. control group; ${ }^{\#} p<0.05$ vs. estrogen group. B, Knockdown of ER $\alpha$ by ER $\alpha$-specific siRNA (siRNA ER $\alpha$ ) in WT-SMCs. The cells were transfected with $50 \mathrm{nM}$ siRNA ER $\alpha$ or negative control siRNA (siRNA C) for $48 \mathrm{~h} .{ }^{*} \mathrm{p}<0.05$. C, Overexpression of ER $\alpha$ in CSE-KO-SMCs. The cells were transfected with the plasmid pEGFP-C1-ER $\alpha$ or control plasmid pEGFP-C1 for $24 \mathrm{~h} .{ }^{*} \mathrm{p}<0.05$. $D$, Knockdown of ER $\alpha$ reversed estrogen-decreased cell viability in WT-SMCs. The cells were transfected with siRNA ER $\alpha$ or siRNA C at $50 \mathrm{nM}$ for $12 \mathrm{~h}$ following another $36 \mathrm{~h}$ treatment with estrogen $(100 \mathrm{nM}) .{ }^{*} p<0.05$ vs. siRNA C group; ${ }^{\#} p<0.05$ vs. siRNA C+estrogen group. $e$, Overexpression of ER $\alpha$ reversed estrogen-increased cell viability in CSE-KO-SMCs. The cells were transfected with pEGFP-C1-ER $\alpha$ plasmid or control plasmid for $24 \mathrm{~h}$ following another $48 \mathrm{~h}$ treatment with estrogen $(100 \mathrm{nM}) .{ }^{*} \mathrm{p}<0.05 \mathrm{vs}$. control vector group; ${ }^{\#} \mathrm{p}<0.05$ vs. control vector+estrogen group. All data were from four independent experiments. doi:10.1371/journal.pone.0041614.g003

potentiated the inhibitory effect of estrogen on cell viability of WTSMCs $(\mathrm{p}<0.05)$ (Figure 2D). On the other hand, neither CSE expression nor $\mathrm{H}_{2} \mathrm{~S}$ production rate was changed by estrogen treatments of WT-SMCs $(\mathrm{p}>0.05)$ (Figure S1A and S1B).

\section{The Role of ER $\alpha$ in Estrogen-altered Cell Growth of WT- SMCs and CSE-KO-SMCs}

To explore whether estrogen receptor mediates the differential effects of estrogen on the growth of WT-SMCs and CSE-KOSMCs, pretreatment of WT-SMCs with ICI 182780 (an ERs inhibitor) significantly reversed estrogen-inhibited cell viability $(\mathrm{p}<0.05)$, and ICI 182780 alone had no effect on cell viability (Figure 3A). Next we manipulated endogenous expression levels of $\mathrm{ER} \alpha$ in both WT-SMCs and CSE-KO-SMCs. Compared with siRNA control group, siRNA ER $\alpha$ at $50 \mathrm{nM}$ significantly inhibited $\mathrm{ER} \alpha$ protein expression in WT-SMCs $(\mathrm{p}<0.05)$ (Figure $3 \mathrm{~B}$ ). The transfection of pEGFP-C1-ER $\alpha$ significantly overexpressed ER $\alpha$ protein in CSE-KO-SMCs when compared with pEGFP control vector $(\mathrm{p}<0.05)$ (Figure 3G). We further found that knockdown of $\mathrm{ER} \alpha$ in WT-SMCs attenuated estrogen-inhibited cell viability in WT-SMCs, but overexpression of $\mathrm{ER} \alpha$ in CSE-KO-SMCs reversed estrogen-enhanced cell viability $(p<0.05)$ (Figure $3 \mathrm{D}$ and $3 \mathrm{E}$ ).

\section{Estrogen-induced Down-regulation of Cyclin D1 in WT- SMCs but up-regulation in CSE-KO-SMCs}

Cyclin D1 plays a critical role in the transition and progress of the cell cycle $[8,13]$. Incubation of WT-SMCs with $100 \mathrm{nM}$ estrogen for $72 \mathrm{~h}$ significantly decreased cyclin Dl expression $(p<0.05)$ (Figure 4A). Quite differently, estrogen significantly increased the expression of cyclin D1 in CSE-KO-SMCs (Figure 4B). Knockdown of ER $\alpha$ in WT-SMCs or overexpression of $\mathrm{ER} \alpha$ in CSE-KO-SMCs markedly reversed estrogen-altered cyclin Dl expression in respective cells $(\mathrm{p}<0.05)$ (Figure $4 \mathrm{C}$ and $4 \mathrm{D})$. Furthermore, overexpression of cyclin D1 in WT-SMCs (Figure 5A) or knockdown of cyclin D1 in CSE-KO-SMCs (Figure 5B) reversed the effect of estrogen on cell viability (Figure 5C and 5D).

\section{Estrogen Activated MAPK in WT-SMCs and CSE-KO-SMCs}

To determine whether estrogen differentially activates MAPK signaling pathways between WT-SMCs and CSE-KO-SMCs, we treated both cells with $100 \mathrm{nM}$ estrogen for different durations. Estrogen treatment resulted in strong activation of ERK, p38 MAPK and JNK in both WT-SMCs and CSE-KO-SMCs (Figure S2A, S2B, S2C). The total amount of MAPK protein remained unchanged with estrogen stimulation. To determine whether MAPK are involved in estrogen-altered cell viability in WT-SMCs and CSE-KO-SMCs, U0126 (a selective inhibitor of the MEK/ ERK signaling pathway), SB203580 (a p38 MAPK inhibitor), SP600125 (a JNK inhibitor), and ICI 182780 were used in the following experiments. We first validated that treatment of WTSMCs and CSE-KO-SMCs with MAPK inhibitors significantly suppressed estrogen-induced phosphorylation of ERK, p38 MAPK and JNK (Figure S3A, S3B, S3C). Blockage of ER activation by ICI 182780 significantly inhibited estrogen-induced phosphorylation of MAPK (Figure S3A, S3B, S3C). SB203580 and SP600125 did not affect estrogen-changed cell viability, but U0126 decreased the viability of both WT-SMCs and CSE-KOSMCs (Figure 6A and 6B). We further found that inhibition of ERK phosphorylation did not affect estrogen-altered expression of cyclin D1 in both WT-SMCs and CSE-KO-SMGs (Figure S4A and $\mathrm{S} 4 \mathrm{~B})$. Therefore, MAPK may not be involved in the effects of estrogen on the growth of both WT-SMCs and CSE-KO-SMCs.

\section{Discussion}

The incidence of proliferative cardiovascular diseases is higher among men than women, but it rises in aging women after the menopause, suggesting a protective role of estrogen [2,21]. $\mathrm{H}_{2} \mathrm{~S}$ is a novel gasotransmitter and provides cardiovascular protection $[7,8,12,15,16,22,23]$. Both $\mathrm{H}_{2} \mathrm{~S}$ and estrogen can inhibit cell proliferation $[3,4,7,8,13]$. However, the interaction between estrogen and $\mathrm{H}_{2} \mathrm{~S}$ as well as its effects on cardiovascular function are not clear.

Estrogen has been used in previous studies at concentrations from $1 \mathrm{pM}$ to $1000 \mathrm{nM}[1,24,25]$. Our present study uses estrogen at the similar range and in most of our experiments $100 \mathrm{nM}$ estrogen was used. In this study, we demonstrated that estrogen significantly reduced the growth of WT-SMCs which produce $\mathrm{H}_{2} \mathrm{~S}$ normally, but increased that of CSE-KO-SMCs which lack the endogenous $\mathrm{H}_{2} \mathrm{~S}$ production (Figure 1). High dose of estrogen $(1000 \mathrm{nM})$ inhibited both cell proliferations, suggesting very higher concentration of estrogen displays a toxic effect and kills the cells via a nonspecific pathway. It is also well known that estrogen at $1000 \mathrm{nM}$ is far beyond of pathophysiological range. We previously showed that over-produced $\mathrm{H}_{2} \mathrm{~S}$ derived from CSE overexpression reduced cell growth and CSE deficiency led to a significant increase in the growth of cultured SMCs $[7,8,26]$. Estrogen may inhibit cell growth by stimulating $\mathrm{CSE} / \mathrm{H}_{2} \mathrm{~S}$ system. However, we found that estrogen has little effect on CSE expression and $\mathrm{H}_{2} \mathrm{~S}$ production. Therefore, it is endogenous $\mathrm{H}_{2} \mathrm{~S}$ level that decides the pro- or anti-growth effect of estrogen on SMCs. However, the mechanism by which $\mathrm{H}_{2} \mathrm{~S}$ assumes this switch role is not clear.

It is generally accepted that estrogen receptors (ERs) mediate the anti-growth effect of estrogen on SMCs [9,27]. Two types of estrogen receptor exist: ERs and estrogen $G$ protein-coupled receptor (GPER) $[27,28]$. ERs include $\mathrm{ER} \alpha$ and $\mathrm{ER} \beta$, which are the members of the nuclear hormone family of intracellular receptors [27]. GPER belong to G protein-coupled receptor [28]. GPER is a new discovered ER at the moment and need to explored in the future. In present study, we only observed the change of $\mathrm{ER} \alpha$ and $\mathrm{ER} \beta$, both of which are DNA-binding transcription factors and expressed in SMCs [27]. Estrogen has been shown to regulate gene transcription by activating both $\mathrm{ER} \alpha$ and $\operatorname{ER} \beta[9,27,29]$. $\mathrm{ER} \beta$ differs from $\mathrm{ER} \alpha$ in 2 important functional domains [29]. The N-terminus containing the activa- 
A
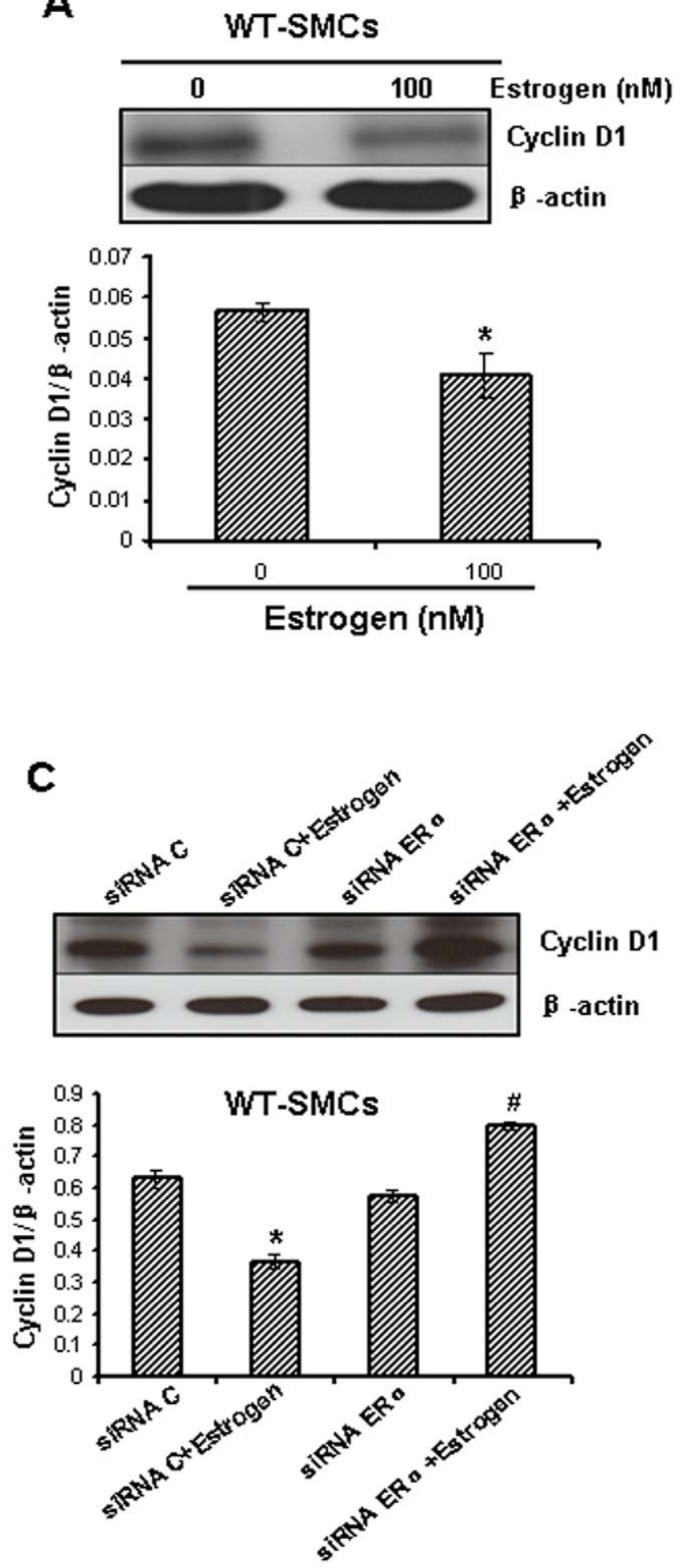

B

\section{CSE-KO-SMCs}
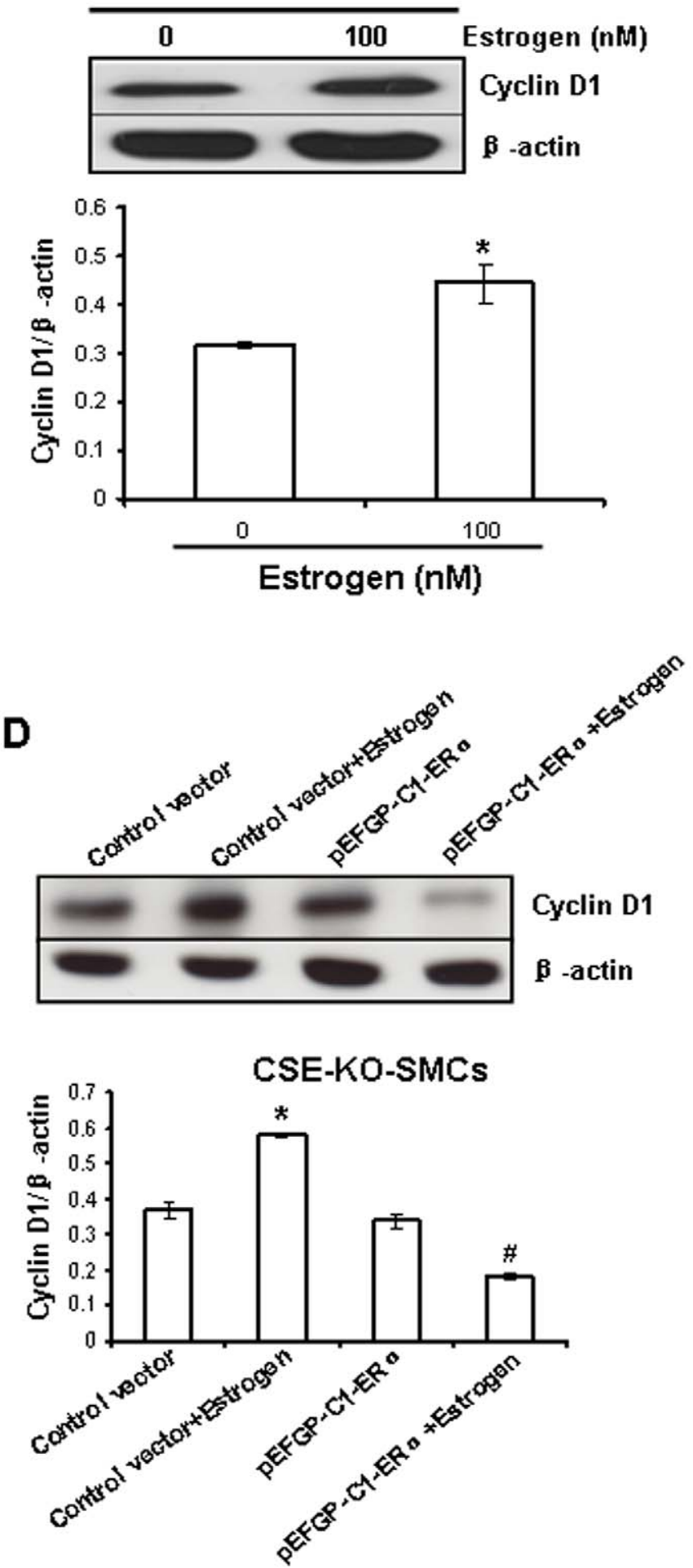

Figure 4. Estrogen altered the expression of cyclin D1. Estrogen reduced the expression of cyclin D1 in WT-SMCs (A) but up-regulated it in CSE-KO-SMCs $(\boldsymbol{B})$. The cells were treated with $100 \mathrm{nM}$ estrogen for $72 \mathrm{~h} .{ }^{*} \mathrm{p}<0.05$. $\boldsymbol{C}$, Knockdown of ER $\alpha$ reversed estrogen-decreased expression of cyclin D1 in WT-SMCs. After transfection with siRNA ER $\alpha$ or siRNA C at $50 \mathrm{nM}$ for $12 \mathrm{~h}$, the cells were incubated with $100 \mathrm{nM}$ estrogen for another $36 \mathrm{~h} .{ }^{*} \mathrm{p}<0.05$ vs. siRNA C group; ${ }^{\#} \mathrm{p}<0.05$ vs. siRNA C or siRNA C+estrogen group. $D$, Overexpression of ER $\alpha$ reversed estrogen-increased expression of cyclin D1 in CSE-KO-SMCs. After transfection with pEGFP-C1-ER $\alpha$ plasmid or control plasmid for $24 \mathrm{~h}$, the cells were incubated with $100 \mathrm{nM}$ estrogen for another $48 \mathrm{~h}$. ${ }^{*} \mathrm{p}<0.05 \mathrm{vs}$. control vector group; ${ }^{\#} \mathrm{p}<0.05 \mathrm{vs}$. control vector or control vector+estrogen group. All data were from three independent experiments.

doi:10.1371/journal.pone.0041614.g004 
A

WT-SMCs
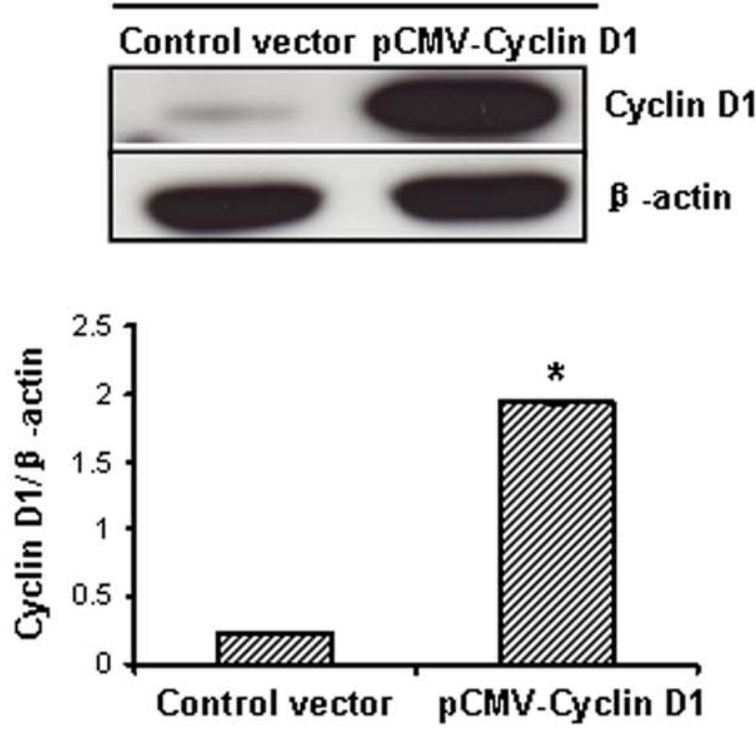

C

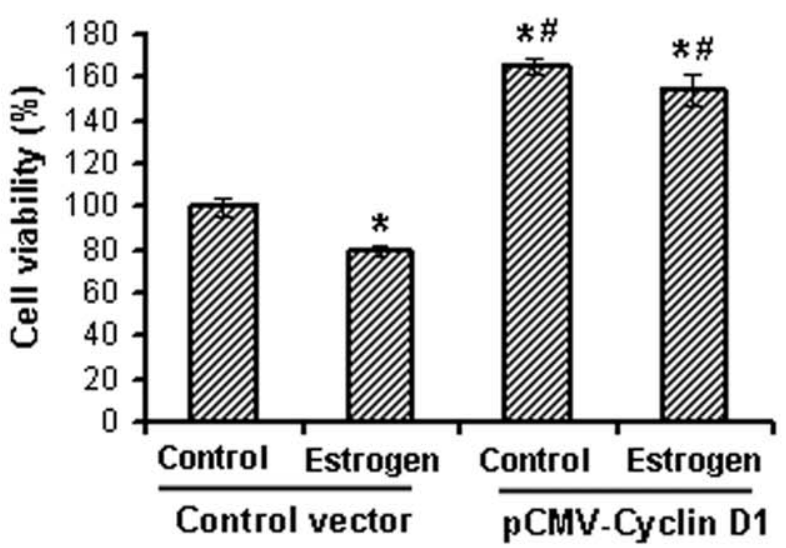

B

\section{CSE-KO-SMCS}

SIRNAC SiRNA Cyclin D1

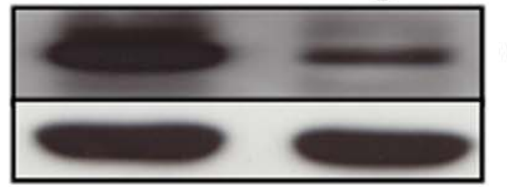

Cyclin D1

B -actin

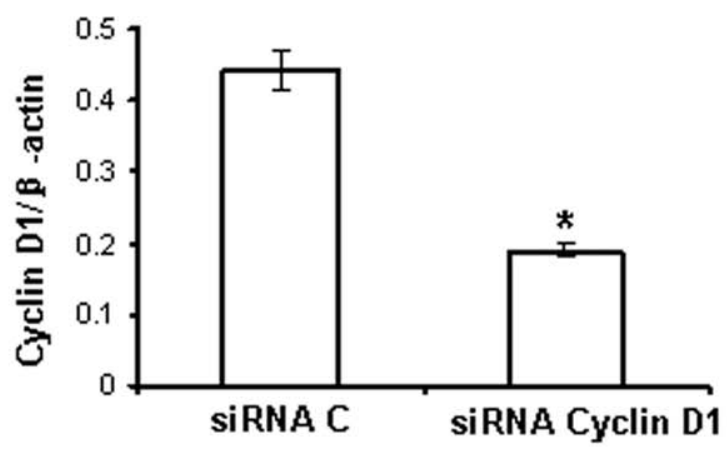

D CSE-KO-SMCs

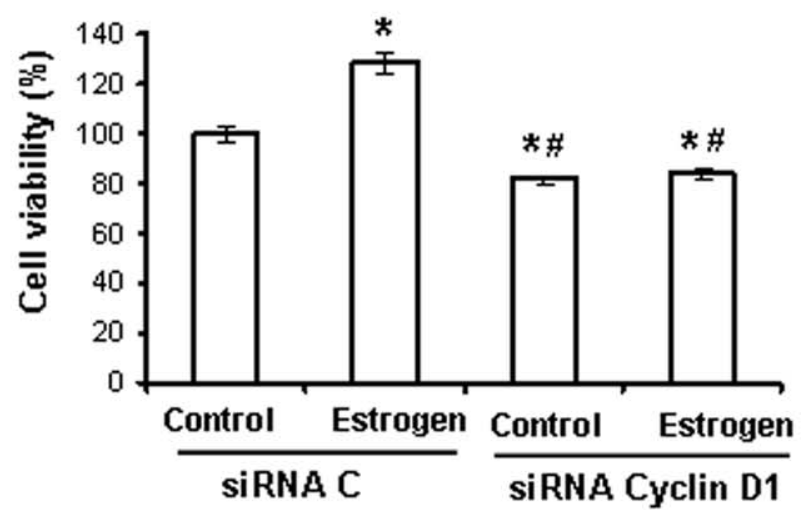

Figure 5. Cyclin D1 mediates estrogen-regulated cell proliferation in WT-SMCs and CSE-KO-SMCs. $A$, Overexpression of cyclin D1 in WTSMCs. The cells were transfected with the vector pCMV-Cyclin D1 or control vector pShuttle-CMV for $24 \mathrm{~h} .{ }^{*} \mathrm{p}<0.05$. $B$, Knockdown of cyclin D1 in CSE-KO-SMCs. The cells were transfected with cyclin D1-specific siRNA (siRNA cyclin D1) or control siRNA (siRNA C) at $50 \mathrm{nM}$ for $48 \mathrm{~h} .{ }^{*} \mathrm{p}<0.05 . C_{,}$ Overexpression of cyclin D1 reversed estrogen-inhibited cell viability in WT-SMCs. The cells were transfected with pCMV-Cyclin D1 or control vector for $24 \mathrm{~h}$ following another $48 \mathrm{~h}$ treatment with $100 \mathrm{nM}$ estrogen. ${ }^{*} \mathrm{p}<0.05 \mathrm{vs}$. control vector+control group, ${ }^{\#} \mathrm{p}<0.05$ vs. control vector+estrogen group. $D$, Knockdown of cyclin D1 reversed estrogen-induced cell viability in CSE-KO-SMCs. The cells were transfected with siRNA cyclin D1 or siRNA C at $50 \mathrm{nM}$ for $12 \mathrm{~h}$ following another $36 \mathrm{~h}$ treatment with $100 \mathrm{nM}$ estrogen. ${ }^{*} \mathrm{p}<0.05$ vs. siRNA $\mathrm{C}$ control group, ${ }^{\#} \mathrm{p}<0.05 \mathrm{vs}$. siRNA C+estrogen group. All experiments were repeated for four times.

doi:10.1371/journal.pone.0041614.g005

tion function-1 (AF-1) domain of $\operatorname{ER} \alpha$ and $\operatorname{ER} \beta$ has only $30 \%$ homology, and the hormone-binding (HBD) domains of $\mathrm{ER} \alpha$ and ER $\beta$ have only $53 \%$ homology [29]. Here, we demonstrated that the expression of $\mathrm{ER} \alpha$ was significantly reduced in the absence of CSE expression but induced by exogenously applied $\mathrm{H}_{2} \mathrm{~S}$. However, CSE deficiency had no effect on the expression of $\mathrm{ER} \beta$, suggesting that $\mathrm{H}_{2} \mathrm{~S}$ may regulate $\mathrm{ER} \alpha$ expression by targeting at the AF-1 or HBD domain. It is not clear at this moment how $\mathrm{H}_{2} \mathrm{~S}$ regulates $\mathrm{ER} \alpha$ expression. $\mathrm{H}_{2} \mathrm{~S}$ can posttranslationally modify the proteins by $S$-sulfhydration [30,31], and it is possible that $\mathrm{H}_{2} \mathrm{~S}$ may $S$-sulfhydrate some transcript factors or proteins, which subsequently stimulate $\mathrm{ER} \alpha$ expression.

Altered $\mathrm{ER} \alpha$ expression or activity contributes to different regulatory roles of estrogen in cell growth between WT-SMCs and CSE-KO-SMCs. First, blockage of ERs activity by ICI 182780 reversed the anti-growth effect of estrogen on WT-SMCs (Figure 3A). Second, supplement of WT-SMCs with exogenously applied $\mathrm{H}_{2} \mathrm{~S}$ at $100 \mu \mathrm{M}$ aggravated the anti-growth effect of estrogen (Figure 2D). Third, when ER $\alpha$ expression was knockdown by ER $\alpha$-specific siRNA in WT-SMCs, estrogen had no effect on SMC growth (Figure 3, B and D). Fourth, overexpression 
A

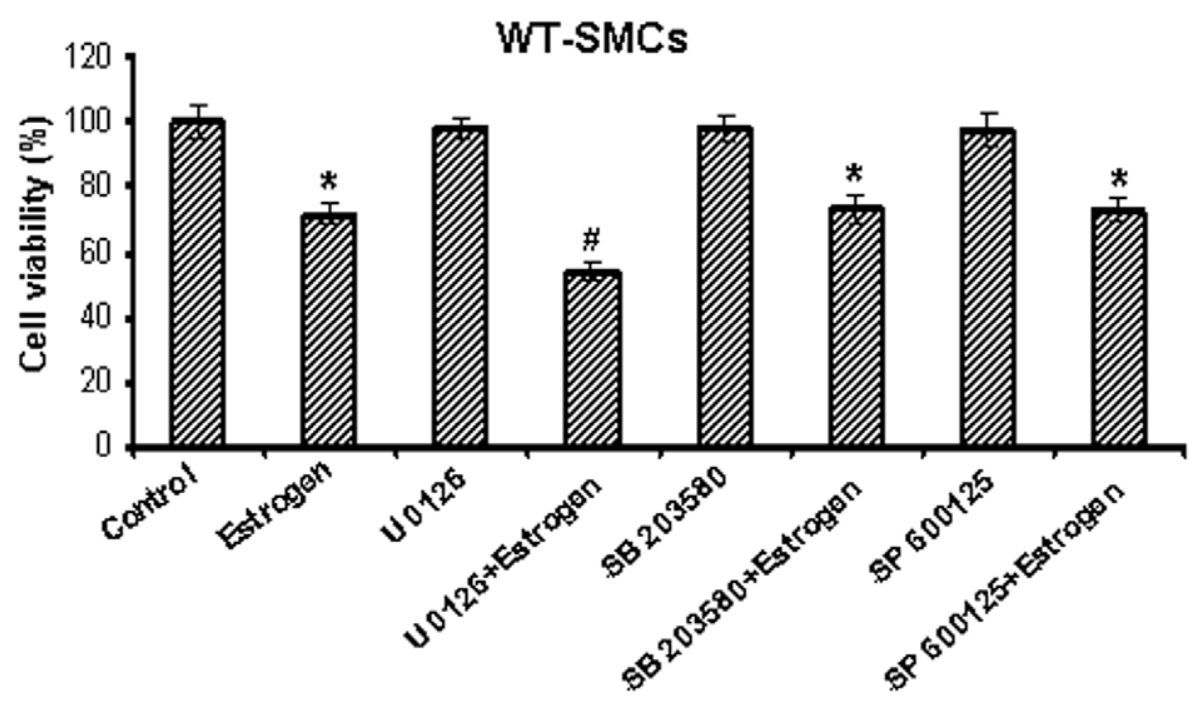

B

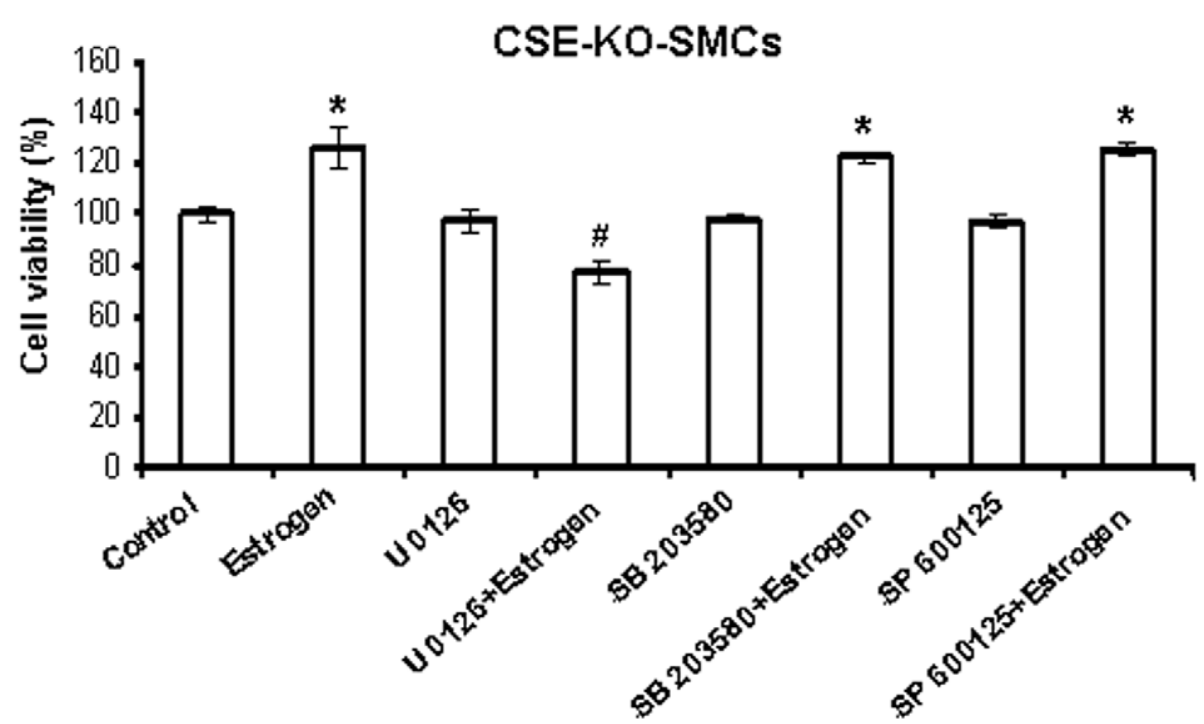

Figure 6. MAPK were not involved in estrogen-altered cell growth in WT-SMCs and CSE-KO-SMCs. WT-SMCS ( $A$ ) and CSE-KO-SMCS (B) were pretreated with $10 \mu \mathrm{M}$ U0126 (a MEK/ERK inhibitor), or $10 \mu \mathrm{M}$ SB 203580 (a p38 MAPK inhibitor), or $10 \mu \mathrm{M}$ SP 600125 (a JNK inhibitor) for $30 \mathrm{~min}$ followed by $100 \mathrm{nM}$ estrogen for additional $72 \mathrm{~h}$. The cell viability was evaluated by MTT assay. The data were from four independent experiments. ${ }^{*} p<0.05$ vs. control group; ${ }^{\#} p<0.05$ vs. estrogen group. doi:10.1371/journal.pone.0041614.g006

of $\mathrm{ER} \alpha$ overturned the pro-growth effect of estrogen in CSE-KOSMCs (Figure 3E). These discoveries indicate the interaction of $\mathrm{H}_{2} \mathrm{~S}$ and $\mathrm{ER} \alpha$ plays a key role in the effects of estrogen on SMC growth.

ERs belong to ligand-activated transcription factors [27,29]. Cyclin D1 is a downstream gene of ERs [9]. The present study found that estrogen at $100 \mathrm{nM}$ significantly inhibited cyclin D1 expression in WT-SMCs, but increased cyclin Dl expression in CSE-KO-SMCs (Figure 4, A and B). Cell cycle progression is determined by the formation of protein complexes among cyclins and cyclin-dependent kinases (cdks), and the association of cyclin D1 with cdk2, cdk4, and cdk6 determines early G1 progression [8]. We have shown before that cyclin Dl is inhibited by exogenously applied $\mathrm{H}_{2} \mathrm{~S}$ or CSE overexpression but induced by CSE deficiency, all of which contribute to the regulatory role of $\mathrm{H}_{2} \mathrm{~S}$ on $\mathrm{SMC}$ growth $[8,13]$. Here, we further found that cyclin D1 mediated the anti-growth effect in WT-SMCs and the progrowth effect in CSE-KO-SMCs by estrogen treatments (Figure 4 and 5), pointing to the critical role of endogenous $\mathrm{H}_{2} \mathrm{~S}$ in $\mathrm{ER} \alpha$ mediated cyclin D1 expression following altered cell growth.

In summary, our study for the first time demonstrates that $\mathrm{H}_{2} \mathrm{~S}$ mediates estrogen-inhibited proliferation of SMCs via selective activation of $\mathrm{ER} \alpha /$ cyclin $\mathrm{D} 1$ pathways. The elucidation of the interaction between $\mathrm{H}_{2} \mathrm{~S}$ and estrogen on the regulation of SMC growth would provide new insight for prevention and treatment of proliferative cardiovascular disease such as atherosclerosis. The 
physiological and pathological implications of the interactions between $\mathrm{H}_{2} \mathrm{~S}$ and estrogen in proliferative vascular diseases merit further investigation.

\section{Supporting Information}

Figure S1 Estrogen had no effect on CSE expression and $\mathbf{H}_{2}$ S production. $\boldsymbol{A}$, The expression of CSE was not changed by estrogen treatments. After WT-SMCs were incubated with the indicated concentration of estrogen for $72 \mathrm{~h}$, the cells were collected and subjected to western blotting with anti-CSE antibody. B, Estrogen did not affect $\mathrm{H}_{2} \mathrm{~S}$ production. After WTSMCs were treated with the indicated concentration of estrogen for $72 \mathrm{~h}, \mathrm{H}_{2} \mathrm{~S}$ production rate was measured. All the results were representative of five individual experiments.

(DOG)

Figure S2 Different activation of MAPK by estrogen between WT-SMCs and CSE-KO-SMGs. Time course of the activation of ERK $(\boldsymbol{A})$, p38 $(\boldsymbol{B})$, and JNK $(\boldsymbol{G})$ induced by estrogen. The graphs represent the optical density of the bands of phosphoMAPK normalized with the expression of total-MAPK. All the experiments were repeated for three times. ${ }^{*} \mathrm{p}<0.05$ vs. 0 min of WT-SMCs; ${ }^{\#} \mathrm{p}<0.05$ vs. 0 min of CSE-KO-SMCs; ${ }^{\$} \mathrm{p}<0.05$ vs. WT-SMCs same time group.

\section{References}

1. Cheng B, Song J, Zou Y, Wang Q Lei YH, et al. (2009) Responses of vascular smooth muscle cells estrogen are dependent on balance between ERK and p38 MAPK pathway activities. Int J Cardiol 134: 356-365.

2. Xing D, Nozell S, Chen Y, Hage F, Oparil S (2009) Estrogen and mechanisms of vascular protection. Arterioscler Thromb Vasc Biol 29: 289-295.

3. Hodges YK, Tung L, Yan X, Graham JD, Horwitz KB, et al. (2000) Estrogen receptors alpha and beta: prevalence of estrogen receptor beta mRNA in human vascular smooth muscle and transcriptional effects. Circulation 101: 1792-1798.

4. Watanabe T, Akishita M, Nakaoka T, Kozaki K, Miyahara Y, et al. (2003) Estrogen receptor beta mediates the inhibitory effect of estradiol on vascular smooth muscle cell proliferation. Cardiovasc Res 59: 734-744.

5. Hall JM, Couse JF, Korach KS (2001) The multifaceted mechanisms of estradiol and estrogen receptor signaling. J Biol Chem 276: 36869-36872.

6. Geraldes P, Sirois MG, Bernatchez PN, Tanguay JF (2002) Estrogen regulation of endothelial and smooth muscle cell migration and proliferation role of p38 and p42/44 mitogen-activated protein kinase. Arterioscler Thromb Vasc Biol 22: $1585-1590$.

7. Yang G, Sun X, Wang R (2004) Hydrogen sulfide-induced apoptosis of human aorta smooth muscle cells via the activation of mitogen-activated protein kinases and caspase-3. FASEB J 18: 1782-1784.

8. Yang G, Wu L, Bryan S, Khaper N, Mani S, et al. (2010) Cystathionine gammalyase deficiency and overproliferation of smooth muscle cells. Cardiovasc Res 86: 487-495.

9. Takahashi K, Ohmichi M, Yoshida M, Hisamoto K, Mabuchi S, et al. (2003) Both estrogen and raloxifene cause G1 arrest of vascular smooth muscle cells. J Endocrino 178: 319-329.

10. Warenycia MW, Goodwin LR, Benishin CG, Reiffenstein RJ, Francom DM, et al. (1989) Acute hydrogen sulfide poisoning: demonstration of selective uptake of sufide by the brain stem by measurement of brain sulfide levels. Biochem Pharmacol 38: 973-981.

11. Zhao W, Wang $\mathrm{R}$ (2002) $\mathrm{H}_{2} \mathrm{~S}$-induced vasorelaxation and underlying cellular and molecular mechanisms. Am J Physiol Heart Circ Physiol 283: H474-H480.

12. Wang $\mathrm{R}$ (2002) Two's a crowd: can $\mathrm{H}_{2} \mathrm{~S}$ be the third endogenous $\mathrm{g}$ aseous trnsmitter? FASEB J 16: 1792-1798.

13. Yang G, Cao K, Wu L, Wang R (2004) Cystathionine gamma-lyase overexpression inhibits cell proliferation via a $\mathrm{H}_{2} \mathrm{~S}$-dependent modulation of ERK1/2 phosphorylation and p21 Cip/WAK-1.$J$ Biol Chem 279: 49199-49205.

14. Zhao W, Zhang J, Lu Y, Wang R (2001) The vasorelaxant effect of $\mathrm{H}_{2} \mathrm{~S}$ as a novel endogenous gaseous $\mathrm{K}_{\text {ATP }}$ channel opener. EMBO J 20: 6008-6016.

15. Wang R (2003) The gasotransmitter role of hydrogen sulfide. Antioxid Redox Signal 5: 493-501.
(DOC)

Figure S3 Mediation of ER $\alpha$ in estrogen-induced activation of MAPK. Cells were treated with $10 \mu \mathrm{M}$ ICI 182780 or $10 \mu \mathrm{M}$ U0126 (a MEK/ERK inhibitor) $(\boldsymbol{A})$ or $10 \mu \mathrm{M}$ SB 203580 (a p38 MAPK inhibitor) $(\boldsymbol{B})$ or $10 \mu \mathrm{M}$ SP 600125 (a JNK inhibitor) $(\boldsymbol{C})$ for $30 \mathrm{~min}$ and followed by $100 \mathrm{nM}$ estrogen treatments for another $30 \mathrm{~min}$. The data were from three independent experiments. * $\mathrm{p}<0.05$ vs. control group; ${ }^{\#} \mathrm{p}<0.05$ vs. estrogen group; ${ }^{\$} \mathrm{p}<0.05$ vs. WT-SMCs same group.

(DOC)

Figure S4 Inhibition of ERK had no effect on estrogenaltered cyclin D1 expression. WT-SMCs $(\boldsymbol{A})$ and CSE-KOSMCs $(\boldsymbol{B})$ were pretreated with $10 \mu \mathrm{M}$ U0126 for $30 \mathrm{~min}$ followed by $100 \mathrm{nM}$ estrogen for $72 \mathrm{~h}$. The data were from three independent experiments. $* \mathrm{p}<0.05 v s$. control group. (DOC)

\section{Author Contributions}

Conceived and designed the experiments: HZL SM WC GDY CL RW. Performed the experiments: HZL SM WC. Analyzed the data: HZL SM WC. Wrote the paper: HZL LYW RW.

16. Yang G, Wu L, Jiang B, Yang W, Qi J, et al. (2008) $\mathrm{H}_{2} \mathrm{~S}$ as a physiologic vasorelaxant: hypertension in mice with deletion of cystathionine gamma-lyase. Science 322: 587-590.

17. Lu Y, Hanna ST, Tang G, Wang R (2002) Contributions of Kv1.2, Kv1.5 and $\mathrm{Kv}$ 2.1 subunits to the native delayed rectifier $\mathrm{K}(\mathrm{t})$ current in rat mesenteric artery smooth muscle cells. Life Sci 71: 1465-1473.

18. Li HZ, Guo J, Gao J, Han LP, Jiang CM, et al. (2011) Role of dopamine D2 receptors in ischemia/reperfusion induced apoptosis of cultured neonatal rat cardiomyocytes. J Biomed Sci 18: 1-11.

19. Cao Q Zhang L, Yang G, Xu G, Wang R (2010) Butyrate-stimulated $\mathrm{H}_{2} \mathrm{~S}$ production in colon cancer cells. Antioxid Redox Signal 12: 1101-1109.

20. Li HZ, Han LP, Jiang CM, Li H, Zhao YJ, et al. (2008) Effect of dopamine receptor 1 on apoptosis of cultured neonatal rat cardiomyocytes in simulated ischaemia/reperfusion. Basic Clin Pharmacol Toxicol 102: 329-336.

21. Arnal JF, Gourdy P, Elhage R, Garmy-Susini B, Delmas E, et al. (2004) Estrogen and atherosclerosis. Eur J Endocrinol 150: 113-117.

22. Wang R (2009) Hydrogen sulfide: a new EDRF. Kidney Int 76: 700-704.

23. Wang R (2011) Signaling pathways for the vascular effects of hydrogen sulfide. Curr Opin Nephrol Hypertens 20: 107-112.

24. Stamatiou R, Paraskeva E, Papagianni M, Molyvdas PA, Hatziefthimiou A (2011) The mitogenic effect of testosterone and $17 \beta$-estradiol on airway smooth muscle cells. Steroids 76: 400-408.

25. Waladali W, Luo Y, Li W, Zheng M, Hu Q (2009) 17Beta-estradiol affects the proliferation and apoptosis of rat bladder neck smooth muscle cells by modulating cell cycle transition and related proteins. World J Urol 27: 241-248.

26. Yang G, Wu L, Wang $\mathrm{R}$ (2006) Pro-apoptotic effect of endogenous $\mathrm{H}_{2} \mathrm{~S}$ on human aorta smooth muscle cells. FASEB J 20: 553-555.

27. Pace P, Taylo J, Suntharalingam S, Coombes RC, Ali S (1997) Human estrogen receptor beta binds DNA in a manner similar to and dimerizes with estrogen receptor alpha. J Biol Chem 272: 25832-25838.

28. Prossnitz ER, Barton M (2011) The G-protein-coupled estrogen receptor GPER in health and disease. Nat Rev Endocrinol 7: 715-726.

29. Kuiper GG, Enmark E, Pelto-Huikko M, Nilsson S, Gustafsson JA (1996) Cloning of a novel estrogen receptor expressed in rat prostate and ovary. Proc Nat Acad Sci USA 93: 5925-5930.

30. Kabil O, Banerjee R (2010) Redox biochemistry of hydrogen sulfide. J Biol Chem 285: 21903-21907.

31. Mustafa AK, Gadalla MM, Sen N, Kim S, Mu W, et al. (2009) $\mathrm{H}_{2} \mathrm{~S}$ signals through protein S-sulfhydration. Sci Signal 2:ra72. 